\title{
19. BOLBOFORMA FROM NORTH ATLANTIC SITES, DEEP SEA DRILLING PROJECT LEG 94
}

\author{
John W. Murray, Department of Geology, University of Exeter, Devon, United Kingdom²
}

\begin{abstract}
Eight species of Bolboforma occur in the middle Miocene to lower Pliocene carbonate oozes and chalks of Sites 400 and 606 to 611. Although they have some biostratigraphic value, this is limited because most species are long-ranging. Also, the data show clearly that Bolboforma is most diverse in high latitudes, which in turn affects the biostratigraphic value of these forms.
\end{abstract}

\section{INTRODUCTION}

Bolboforma von Daniels and Spiegler, 1974, is a problematic microfossil first recorded from the Tertiary of Germany. It is now known to be widespread in European Tertiary shelf sediments (Willems, 1976; Odrzywolska-Bienkova, 1976; Szczechura, 1982; King, 1983) and in deep-sea sediments from the Mediterranean (Bizon et al., 1977), North Atlantic (L. Molinsky, in Rögl and Hochuli, 1976; Murray, 1979, 1984), and off Antarctica (Rögl and Hochuli, 1976). In this chapter, the occurrence of Bolboforma is reported from Sites 606 through 611 of Leg 94 and also from Hole 400A of Leg 48 (Table 1, Fig. 1). The biostratigraphy is based on the site reports in the respective volumes.

\section{MATERIALS AND METHODS}

Core-catcher samples were studied from Sites 606 to 611 (Table 1). Those from Sites 606,607 , and 608 had already been processed by Dr. P. Weaver. Samples from Hole 400A were supplied from the DSDP core repository. Each sample was dried at $60^{\circ} \mathrm{C}$, soaked in a dilute solution of calgon (sodium hexametaphosphate), and then washed on a $63-\mu \mathrm{m}(230 \mathrm{mesh})$ sieve. The residue was dried at $60^{\circ} \mathrm{C}$ and then split on a $125-\mu \mathrm{m}$ ( $125 \mathrm{mesh})$ sieve. Only the fraction $>125 \mu \mathrm{m}$ was examined. The age range of the samples is from early Miocene (NN2) to early Pliocene (NN16). Altogether 107 samples were examined, of which 31 contained Bolboforma. All the species recorded here are illustrated in Murray (1984).

\section{DATA}

Those samples that yielded Bolboforma are listed in Table 2; those that are barren are listed in Table 3. The biostratigraphic distribution is shown in Table 4, which also shows the ranges recorded at Sites 552 to 555 off Rockall Plateau. For B. aculeata, B. costata, B. danielsi, $B$. intermedia, and $B$. reticulata, the ranges recorded here are consistent with those from Rockall, but generally incomplete. For $B$. clodiusi and $B$. laevis, the range is extended down to Zone NN5, compared with Zone NN6 at Sites 552 through 555. At Rockall, B. metzmacheri was found in Zones NN1 and NN6 through 16, so the record at Sites 609 to 611 and 400 in Zone NN5 is consistent with this.

\footnotetext{
${ }^{1}$ Ruddiman, W. F., Kidd, R. B., Thomas, E., et al., Init. Repts. DSDP, 94: Washington (U.S. Govt. Printing Office).

2 Address: Dept. of Geology, University of Exeter, Devon, EX4 4QE United Kingdom.
}

Table 1. Position of holes at Sites 606 to 611 and 400.

\begin{tabular}{lccc}
\hline Site/hole & Latitude (N) & Longitude (W) & Depth (m) \\
\hline 606 & $37^{\circ} 20.32^{\prime}$ & $35^{\circ} 29.99^{\prime}$ & 3007 \\
$607 \mathrm{~A}$ & $41^{\circ} 00.07^{\prime}$ & $32^{\circ} 57.44^{\prime}$ & 3427 \\
608 & $42^{\circ} 50.21^{\prime}$ & $23^{\circ} 05.25^{\prime}$ & 3526 \\
$609 \mathrm{~B}$ & $49^{\circ} 52.67^{\prime}$ & $24^{\circ} 14.29^{\prime}$ & 3884 \\
$610,610 \mathrm{~A}$ & $53^{\circ} 13.30^{\prime}$ & $18^{\circ} 53.21^{\prime}$ & 2417 \\
$610 \mathrm{E}$ & $53^{\circ} 13.47^{\prime}$ & $18^{\circ} 53.69^{\prime}$ & 2445 \\
$611 \mathrm{C}$ & $52^{\circ} 50.15^{\prime}$ & $30^{\circ} 19.10^{\prime}$ & 3230 \\
$400 \mathrm{~A}$ & $47^{\circ} 22.9^{\prime}$ & $09^{\circ} 11.9^{\prime}$ & 4399 \\
\hline
\end{tabular}

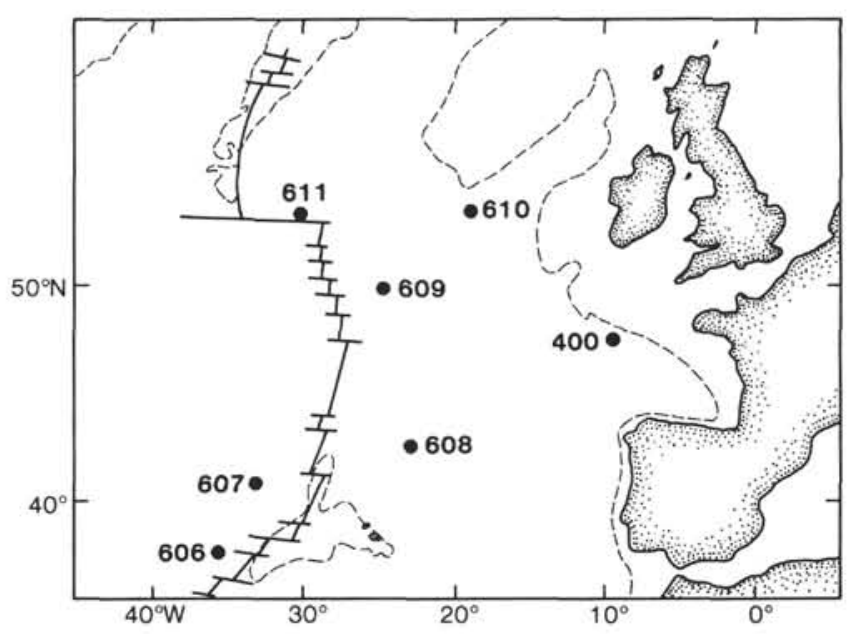

Figure 1. Map showing the position of the sites. (Dashed line $=2000-\mathrm{m}$ isobath.)

The significance of the biostratigraphic distribution has to be judged in the light of ecological controls on the distribution of Bolboforma. In Table 5 a comparison is made of the number of species present in each zone at sites arranged in a north-south sequence from Sites 552 to 555 , at latitudes of 56 to $57^{\circ}$, to Sites 607 and 606 at latitudes of 37 to $41^{\circ} \mathrm{N}$. A clear pattern is evident. In Zones NN6 to NN11 the Rockall Sites 552 through 555 are more diverse, with 5 to 7 species, than those to the south, with 0 to 3 species. Furthermore, those levels where Bolboforma is common (rather than present or rare) are mainly confined to the Rockall area and Sites 611 and 610, which are closest to it. 
Table 2. Occurrence of Bolboforma in Leg 94 samples and Hole 400A.

\begin{tabular}{|c|c|c|c|c|c|c|c|c|c|c|c|}
\hline \multirow[b]{2}{*}{$\begin{array}{c}\text { Sample } \\
\text { (core-section, } \\
\text { interval in } \mathrm{cm} \text { ) }\end{array}$} & \multirow[b]{2}{*}{$\begin{array}{l}\text { sँ๊ } \\
\text { ปूँ } \\
\infty \\
\infty\end{array}$} & \multirow[b]{2}{*}{ 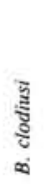 } & \multirow[b]{2}{*}{ 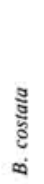 } & \multirow[b]{2}{*}{$\begin{array}{l}\frac{3}{3} \\
\frac{5}{5} \\
\infty\end{array}$} & \multirow[b]{2}{*}{ 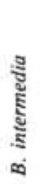 } & \multirow[b]{2}{*}{$\frac{n}{\Delta}$} & \multirow[b]{2}{*}{ 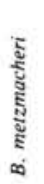 } & \multirow[b]{2}{*}{ 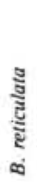 } & \multicolumn{2}{|c|}{ Abundance } & \multirow[b]{2}{*}{ Zone } \\
\hline & & & & & & & & & 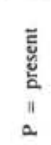 & $\begin{array}{l}\text { ह } \\
\text { E⿱ } \\
\text { E } \\
\text { "I } \\
0\end{array}$ & \\
\hline $608-18, \mathrm{CC}$ & - & - & - & - & - & - & - & - & $\mathbf{P}$ & & NN11 \\
\hline $608-19, \mathrm{CC}$ & - & - & - & - & $r$ & - & - & - & P & & NNII \\
\hline $608-20, \mathrm{CC}$ & - & $r$ & - & - & - & - & - & - & P & & NNII \\
\hline $608-21, C C$ & - & - & - & - & r & - & - & - & $\mathbf{P}$ & & NNII \\
\hline $608-22, C C$ & - & - & - & - & - & - & - & - & P & & NNII \\
\hline $608-23, \mathrm{CC}$ & - & - & - & - & - & - & - & - & P & & NN9 \\
\hline $608-25, \mathrm{CC}$ & $r$ & - & - & - & r & - & - & - & & $\mathrm{C}$ & NN7 \\
\hline $609 \mathrm{~B}-30, \mathrm{CC}$ & - & $r$ & - & - & - & - & - & - & P & & $\mathrm{NN} 13$ \\
\hline $609 \mathrm{~B} \cdot 36, \mathrm{CC}$ & - & r & - & - & - & - & r & r & & C & NNII \\
\hline $610-11, \mathrm{CC}$ & - & - & - & - & - & - & - & - & P & & NNII \\
\hline $610-12, \mathrm{CC}$ & - & - & - & - & - & 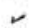 & - & - & P & & NN $10-7$ \\
\hline $610-13, \mathrm{CC}$ & - & r & - & - & - & - & - & - & & C & NN10-7 \\
\hline $610-14, \mathrm{CC}$ & - & - & - & - & - & 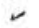 & - & - & & C & NNIO-7 \\
\hline $610-15, \mathrm{CC}$ & - & $r$ & - & - & $r$ & r & - & - & & C & NN8-7 \\
\hline $610-16, C C$ & - & 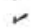 & - & $r$ & - & - & - & - & & C & NN6 \\
\hline $610-17, \mathrm{CC}$ & - & r & - & - & - & - & $r$ & - & & C & NN5 \\
\hline $610 \mathrm{E}-2, \mathrm{CC}$ & - & $r$ & - & - & - & - & - & - & $\mathbf{P}$ & & NNII \\
\hline $610 \mathrm{E}-6, \mathrm{CC}$ & - & r & - & - & $r$ & - & - & - & P & & NN11 \\
\hline $610 \mathrm{E}-7, \mathrm{CC}$ & - & - & - & - & - & r & $r$ & - & & C & NN10 \\
\hline $611 \mathrm{C}-22, \mathrm{CC}$ & - & - & r & - & - & - & - & - & $\mathbf{P}$ & & NN15 \\
\hline $611 C-35, C C$ & - & r & - & - & - & - & - & - & $\mathrm{P}$ & & NNII \\
\hline $611 \mathrm{C}-43, \mathrm{CC}$ & - & - & - & - & - & - & - & - & P & & NN11 \\
\hline $611 \mathrm{C}-44, \mathrm{CC}$ & - & - & - & - & - & - & - & - & & C & NN10 \\
\hline $611 \mathrm{C}-45, \mathrm{CC}$ & - & - & - & - & - & - & 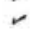 & - & & C & NN10 \\
\hline $611 \mathrm{C}-46, \mathrm{CC}$ & - & - & - & - & - & $r$ & 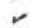 & - & & c & NNIO \\
\hline $611 \mathrm{C}-47, \mathrm{CC}$ & - & - & - & - & - & 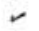 & - & - & & C & NNIO \\
\hline $400 \mathrm{~A}-20-5,53-55$ & - & - & - & - & r & - & - & - & $P$ & & NNII \\
\hline $400 \mathrm{~A}-27-1,130-132$ & - & r & - & - & - & - & - & - & $\mathrm{P}$ & & NN8 \\
\hline $400 \mathrm{~A}-29-1,138-140$ & - & - & - & - & - & - & - & - & P & & NN7 \\
\hline $400 \mathrm{~A}-35-3,119-121$ & - & $\sim$ & - & - & - & - & - & - & P & & NN5 \\
\hline $400 \mathrm{~A}-36-2,20-22$ & - & - & - & - & - & r & - & - & $\mathbf{P}$ & & NN5 \\
\hline
\end{tabular}

Note: $\boldsymbol{\nu}=$ present $-\boldsymbol{=}$ absent

Table 3. List of samples in which Bolboforma was not found in the $>125-\mu \mathrm{m}$ fraction (based on the examination of a split containing at least 1000 planktonic foraminifers).

\begin{tabular}{|c|c|c|c|c|c|c|c|}
\hline $\begin{array}{l}\text { Hole } \\
606\end{array}$ & $\begin{array}{l}\text { Hole } \\
607 \mathrm{~A}\end{array}$ & $\begin{array}{c}\text { Hole } \\
608\end{array}$ & $\begin{array}{l}\text { Hole } \\
609 \mathrm{~B}\end{array}$ & $\begin{array}{c}\text { Hole } \\
610\end{array}$ & $\begin{array}{l}\text { Hole } \\
610 \mathrm{~A}\end{array}$ & $\begin{array}{l}\text { Hole } \\
611 \mathrm{C}\end{array}$ & $\begin{array}{l}\text { Hole } \\
400 \mathrm{~A}\end{array}$ \\
\hline $\begin{array}{l}8, \mathrm{CC} \\
\text { through } \\
18, \mathrm{CC}\end{array}$ & $\begin{array}{l}19, \mathrm{CC} \\
\text { through } \\
26, \mathrm{CC}\end{array}$ & $\begin{array}{l}5, \mathrm{CC} \\
\text { through } \\
17, \mathrm{CC} \\
24, \mathrm{CC}\end{array}$ & $\begin{array}{l}19, \mathrm{CC} \\
20, \mathrm{CC} \\
21, \mathrm{CC} \\
23, \mathrm{CC} \\
25, \mathrm{CC} \\
26, \mathrm{CC} \\
27, \mathrm{CC} \\
28, \mathrm{CC} \\
32, \mathrm{CC} \\
33, \mathrm{CC} \\
34, \mathrm{CC}\end{array}$ & $\begin{array}{l}6, \mathrm{CC} \\
7, \mathrm{CC} \\
8, \mathrm{CC} \\
9, \mathrm{CC} \\
10, \mathrm{CC} \\
18, \mathrm{CC} \\
19, \mathrm{CC} \\
20, \mathrm{CC} \\
22, \mathrm{CC} \\
23, \mathrm{CC} \\
24, \mathrm{CC} \\
25, \mathrm{CC}\end{array}$ & $21, \mathrm{CC}$ & $\begin{array}{l}15, \mathrm{CC} \\
17, \mathrm{CC} \\
19, \mathrm{CC} \\
21, \mathrm{CC} \\
24, \mathrm{CC} \\
26, \mathrm{CC} \\
28, \mathrm{CC} \\
30, \mathrm{CC} \\
32, \mathrm{CC} \\
39, \mathrm{CC}\end{array}$ & $\begin{array}{l}4-5,92-94 \\
6-3,105-106 \\
8-6,36-38 \\
11-2,22-24 \\
14-2,22-24 \\
15-4,22-24 \\
17-3,106-108 \\
18-4,106-108 \\
37-4,114-116\end{array}$ \\
\hline
\end{tabular}

\section{DISCUSSION}

Although Daniels and Spiegler (1974) established that Bolboforma has some stratigraphic value in the European Tertiary, it is clear that most species are long-ranging and of limited value. The extension of the range from the Miocene into the lower Pliocene recorded by Murray (1984) is confirmed by this study.

The Leg 94 material strongly supports the speculation by Murray (1984) that Bolboforma might be most diverse and most abundant in high latitudes. The highest numbers of individuals occur in drift deposits (probably because of their fine grain size), but the diversity values are clearly independent of this influence. The diversity is moderate in the drift deposits of Sites 610 and 611 even though the abundance of individuals is high.
Table 4. Biostratigraphic distribution of Bolboforma.

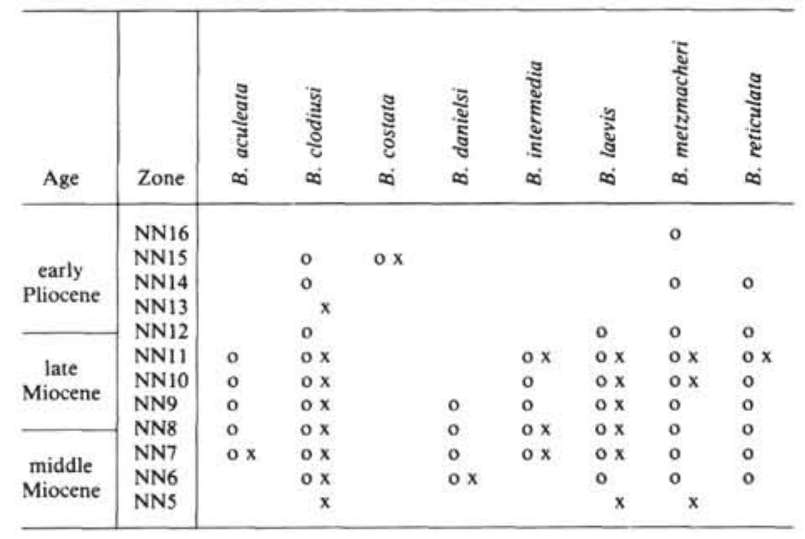

Note: $\mathrm{x}=$ range recorded in this chapter; $\mathrm{o}=$ range recorded by Murray (1984) for Sites 552 through 556 .

Table 5. Number of Bolboforma species at Northeast Atlantic sites.

\begin{tabular}{lcccccc}
\hline Sites & NN11 & NN10 & NN9 & NN8 & NN7 & NN6 \\
\hline $552-555$ & 6 & $6^{\mathrm{x}}$ & $7^{\mathrm{x}}$ & $7^{\mathrm{x}}$ & $7^{\mathrm{x}}$ & $5^{\mathrm{x}}$ \\
611,610 & 3 & $3^{\mathrm{x}}$ & - & $3^{\mathrm{x}}$ & $3^{\mathrm{x}}$ & $2^{\mathrm{x}}$ \\
609 & $3^{\mathrm{x}}$ & - & - & - & - & - \\
400,119 & 2 & - & - & 2 & 2 & - \\
608 & 3 & - & 1 & 0 & $3^{\mathrm{x}}$ & - \\
607,606 & 0 & - & - & - & - & - \\
\hline
\end{tabular}

Note: $-=$ not sampled or not represented. Data for Sites 552 through 555 and 119 , from Murray (1984). ${ }^{X}=$ common (i.e., several per $10-\mathrm{cm}^{2}$ picking tray); all figures that are not so marked are present to rare.

\section{ACKNOWLEDGMENTS}

Dr. P. Weaver of the Institute of Oceanographic Sciences kindly made available the samples from Leg 94. Mrs. V. Ellis and Miss. J. Eggins typed the manuscript.

\section{REFERENCES}

Bizon, G., Tauourdeau-Lantz, J., and Wright, R., 1977. Présence d'algues enkystées: Pachysphaera et de microfossiles d'affinités incertaines: Bolboforma dans le Miocène de Mediterranée. Rev. Micropal., 20:140-146.

Daniels, C. H., von, and Spiegler, D., 1974. Bolboforma n. gen. (Protozoa?)-eine neue stratigraphisch wichtige Gattung aus dem Oligozän/Miozän Nordwestdeutschlands. Palaont. Zeitschr., 48:57-76.

King, C., 1983. Cainozoic micropalaeontological biostratigraphy of the North Sea. Rep. Inst. Geol. Sci., 82(7):1-40.

Murray, J. W., 1979. Cenozoic biostratigraphy and paleoecology of Sites 403 to 406 based on the foraminifers. In Montadert, L., Roberts, D. G., et al., Init. Repts. DSDP, 48: Washington (U.S. Govt. Printing Office), 415-430.

1984. Biostratigraphic value of Bolboforma, Leg 81, Rockall Plateau. In Roberts, D. G., Schnitker, D., et al., Init. Repts. DSDP, 81: Washington (U.S. Govt. Printing Office), 535-539.

Odrzywolska-Bienkova, E., 1976. O niekórych gatunkach z rodzaju Bolboforma (Protozoa?) W miocenie Polski. Kwart. Geol., 20:551558.

Rögl, F., and Hochuli, P., 1976. The occurrence of Bolboforma, a probable algal cyst, in the Antarctic Miocene of DSDP Leg 35. In Hollister, C. D., Craddock, C., et al., Init. Repts. DSDP, 35: Washington (U.S. Govt. Printing Office), 713-719.

Szczechura, J., 1982. Middle Miocene foraminiferal biochronology and ecology of southeastern Poland. Acta Paleont. Polonica, 27:3-44.

Willems, W., 1976. The genus Bolboforma von Daniels and Spiegler in the Upper Miocene of Northern Belgium. Bull. Soc. Belge. Geol., $85: 31-38$.

Date of Initial Receipt: 12 October 1984

Date of Acceptance: 7 May 1985 